\title{
Corporate governance and intellectual capital
}

\author{
Rahmat Alizadeh $^{\mathrm{a}^{*}}$, Seyed Ali Nabavi Chashmi ${ }^{\mathrm{b}^{*}}$ and Asghar Jahani Bahnamiri ${ }^{\mathrm{c}}$
}

${ }^{a}$ Department of Business Management, Babol Branch, Islamic Azad University, Babol, Iran

${ }^{b}$ Assistant Professor Department of Business Management, Babol Branch, Islamic Azad University, Babol, Iran

${ }^{c}$ M.A., Department of Business Management, Babol Branch, Islamic Azad University (IAU), Babol, Iran

\section{CH R ON I C L E A B S T RACT}

Article history:

Received August 25, 2013

Received in revised format

19 September 2013

Accepted 23 October 2013

Available online

November 112013

Keywords:

Tehran Stock Exchange

Intellectual capital

Corporate governance

Pharmaceutical firms

\begin{abstract}
The purpose of this paper is to examine the association between corporate governance and Intellectual capital in the pharmaceutical companies accepted in Tehran Stock Exchange over the period 2004-2009 using a regression based model. The study investigates the impacts of three some independent variables of the corporate governance (i.e. the number of board members, the relative extent of nonexecutive to executive directors, the auditing committee). The results suggest that corporate governance had no special effect on intellectual capital in the pharmaceutical companies. Furthermore among corporate governance's variables, the first one (i.e. board size) had negative impact on firms' intellectual capital and the second and the third variables had no effects on intellectual capital.
\end{abstract}

\section{Introduction}

During the past few years, there have been tremendous efforts on learning more about different factors influencing the performance of firms listed on various stock exchanges (Ballas et al. 2012; Chau \& Leung, 2006; Chi \& Wang, 2010; Solomon \& Solomon, 2004). Intellectual capital is an intangible asset taken into account as a competitive advantage for different firms and it can extend the market share through the necessary knowledge and resources (Lu et al., 2010). Intellectual capital can also be considered as a valuable source for measuring the firms' growth. Corporate governance, on the other hand, plays essential role on making important investment decisions and there are literally various studies associated with the effects of corporate governance on different items such as intellectual capital.

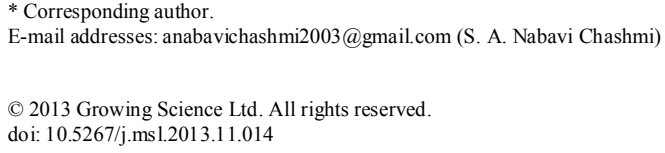


Hentati and Jilani (2013) analyzed the determinants of non-audit-fees for a sample of some French firms belonging to the SBF 120 index over the period 2005-2007. In this study, the attention focused on the effect of shareholder/creditor agency expenses such as debts and investment opportunities. They reported that the affiliation of the auditor to an international network, the presence of an audit committee, the debt, the size of the company and the closing date had an impact on non-audit fees. However, investment opportunities did not influence the amount of non-audit fees.

According to Emamgholipour et al. (2013), institutional investors play important role on formation of various changes on corporate governance systems. They can significantly influence on firms by carefully looking into the performance of management and limiting their opportunistic behaviors and manipulating their financial statements. They studied the relationship between institutional investors and earnings management on some listed companies on Tehran Stock Exchange by investigating a sample of 700 firm-years data over the period 2006-2010. They reported that there was a positive and significant relationship between institutional investors and earnings management and recommended that increasing the ownership percentage of institutional shareholders could increase earnings management.

Rouhi and Khalifehsultani (2012) performed an investigation on relationship between moral hazard and corporate governance with earning forecast quality in the Tehran Stock Exchange. They concluded that moral hazard did not impact forecasted earning, significantly. However, there was a meaningful relationship between forecasted earning and quality of earning.

Valahzaghard and Salehi (2012) studied the effect of the corporate governance characteristics and ownership on earnings quality among some Iranian private banks. In their survey, among various factors, the effect of big five shareholder were considered to be significant and positive on earning quality. Besides, the impact of one variable regression test disclosed that institutional ownership had positive impact on earning quality. However, the effects of other variables including percentage of ownership concentration, the size of board of directors, reliance on debt, logarithm of sum of assets, return of assets, logarithm of operating cash flow on earning quality were not meaningful. The result of this survey indicated that institutional ownership played an important role earning quality simply because institutions normally had the access on professionals to control management.

Nassreddine and Anis (2012) determined the mental models of actors in the firm with respect to the stakeholder approach of corporate governance. They used the cognitive map to view these diagrams to show the ways of thinking and conceptualization of the stakeholder approach. The paper also took a corporate governance perspective, discussed stakeholder model.

\section{The proposed study}

The proposed study of this paper considers the following three hypotheses on Intellectual capital (IC),

1. First hypothesis: board size influences on the IC indexes

2. Second hypothesis: The proportion of non-executive members to executive member of the board influences on the IC indexes

3. Third hypothesis: The auditing committee influences on the IC indexes

In this research, IC is considered as a dependent variable and corporate governance (CG) mechanisms components including the number of the board, the percent of non-executive members to executive members in the board as well as the auditing committee are considered as independent variables. IN addition, return on assets (ROA) and total assets to stockholder's equity and natural logarithm of annual sale are considered as control variables. This study deals with testing the effect of corporate governance on intellectual capital and tries to develop practical knowledge about the quality of 
relationships and effectiveness between them, so the study is considered as an applied and descriptive-survey type.

All the pharmaceutical firms accepted in Tehran Stock Exchange (TSE) comprised the population of this study. For sampling the firms only with these four characteristics were selected.

1) The end of their financial year would be in March, which is the end of the year in Iran.

2) The shares of the firms must have been traded on TSE over the period 2004- 2009.

3) There should not be any changes on the financial over the period 2004- 2009.

4) The required information should be available.

Considering above limitations, 28 firms were selected as sample for 6 year; so it is equivalent to 168 year-firm 8 Data collection and analysis.

In this study, because of doing field analysis and dealing with the real data of the pharmaceutical firms accepted in TSE, by due attention to research variables, data were collected from these firms, income statements by different sources for example: compact disk of Tehran stock exchange organization, related software's such as Tadbir pardaz and Rahavar navin and Informative sits of stock exchange organization. After totalizing and doing required calculation by Excell software, It has been ready for analysis. Final analysis has done by Eviews software. For testing the effects of corporate governance mechanisms on intellectual capital, the following regression model is used,

$I C_{i, t}=\beta_{0}+\beta_{1}$ BRDSIZE $_{i, t}+\beta_{2} \operatorname{NONEXEC}_{i, t}$ to EXEC $C_{i, t}+\beta_{3} A U D_{i, t}+\beta_{4} N L S_{i, t}+\beta_{5} R O A_{i, t}$

Where $I C$ is the Intellectual Capital, BRDSIZE represents board size, NONEXEC to EXEC denotes the proportion of non-executive members to executive members of the board, $A U D$ is a dummy variable, which is equal to one if firm's auditing committee do the auditing affairs of the firm, and zero, otherwise. In addition, $N L S$ is the natural logarithm of annual sale, ROA represents return on assets and $\beta$ denotes the variables' coefficient

\section{The results}

\subsection{Descriptive statistics}

For analyzing the basic characteristics of variables, it is necessary to identify the sample and to become familiar with descriptive indicator related to variables. Table 1 demonstrates the summary of the descriptive statistics of the research variables including mean, median and variation parameters as variance, standard deviation and skewness of the variables.

\section{Table 1}

The Results of descriptive indicators

\begin{tabular}{lcccccc}
\hline Variable Type & variable & mean & median & variance & Standard deviation & skewness \\
\hline Dependent & IC & 15.082 & 6.476 & 2860.653 & 53.485 & 5.487 \\
\hline Independent & Board size & 5.047 & 5 & 0.069 & 0.0263 & 4.069 \\
& NON EXEX to EXEC & 0.466 & 0.25 & 0.141 & 0.376 & 1.616 \\
& AUD & 0.178 & 0 & 0.147 & 0.384 & 1.693 \\
\hline Control & ROA & 0.225 & 0.224 & 0.010 & 0.101 & 0.298 \\
& Ln Sales & 5.5 & 5.474 & 0.117 & 0.342 & -0.09 \\
\hline
\end{tabular}

\subsection{Inferential statistics}

The results of these research hypotheses are presented in Table 2 as follows, 
Table 2

The results of compound regression test

\begin{tabular}{|c|c|c|c|c|c|c|}
\hline Variable & Coefficient & Standard Deviation & T-value & PROB & Relationship & Significance Level \\
\hline IC & -34.22219 & 7.947682 & -4.305 & 0.000 & Negative & $99 \%$ \\
\hline BRDSIZE & -1.319498 & 0.506512 & -2.605 & 0.010 & Negative & $951 \%$ \\
\hline NONEXEC TO & 0.319705 & 0.509405 & 0.62760 & 0.531 & No relation & - \\
\hline AUD & 0.531480 & 0.504010 & 1.05450 & 0.294 & No relation & - \\
\hline NLS & 10.77507 & 1.380322 & 7.80619 & 0.000 & Positive & $99 \%$ \\
\hline \multirow[t]{2}{*}{ ROA } & 13.11084 & 2.447006 & 5.35791 & 0.000 & Positive & $99 \%$ \\
\hline & $\begin{array}{c}\text { Determinate } \\
\text { coefficient }\end{array}$ & $\begin{array}{c}\text { Adjusted } \\
\text { Determinate } \\
\text { Coefficient }\end{array}$ & $\begin{array}{c}\text { Mean Deviation } \\
\text { Of regression }\end{array}$ & f-value & F probability & D-W \\
\hline $\begin{array}{l}\text { Weighted } \\
\text { Quantities }\end{array}$ & 0.967503 & 0.956145 & 57.604453 & 85.182 & 0.000000 & 2.391105 \\
\hline $\begin{array}{l}\text { Non-weighted } \\
\text { quantities }\end{array}$ & 0.978757 & -- & -- & -- & -- & 2.315910 \\
\hline
\end{tabular}

\subsection{Testing hypotheses}

\subsubsection{The first hypothesis}

The first hypothesis of the survey investigates whether there is a meaningful relationship between board size and intellectual capital of the pharmaceutical firms accepted in Tehran stock Exchange or not.

$\mathrm{H}_{01}$ ) There is not any meaningful relationship between board size and Intellectual capital of the pharmaceutical firms accepted in Tehran stock Exchange.

$\mathrm{H}_{01}: \mathrm{B}_{\mathrm{i}}=0$

$\mathrm{H}_{11}$ ) There is a meaningful relationship between board size and Intellectual capital of the pharmaceutical firms accepted in Tehran stock Exchange.

$\mathrm{H}_{11}: \mathrm{B}_{\mathrm{i}} \neq \mathrm{O}$

As shown in Table 2, the variable coefficient of board size is -1.316498 . According to t-statistic and $\mathrm{p}$-value of this variable, we conclude that the coefficient is significant at the 0.05 level. So board size has negative meaningful relation with intellectual capital and $\mathrm{H}_{1}$ assumption of the first hypothesis is accepted.

\subsubsection{The second hypothesis}

The second hypothesis of the survey investigates whether the proportion of non- executive members to executive members of the board has a meaningful relationship with intellectual capital of the pharmaceutical firms accepted in Tehran stock Exchange.

$\mathrm{H}_{02}$ ) The proportion of non- executive members to executive members of the board doesn't have a meaningful relationship with Intellectual capital of the pharmaceutical firms accepted in Tehran stock Exchange.

$\mathrm{H}_{02}: \mathrm{B}_{\mathrm{i}}=0$

$\mathrm{H}_{12}$ ) The proportion of non- executive members to executive members of the board has a meaningful relationship with Intellectual capital of the pharmaceutical firms accepted in Tehran stock Exchange.

$\mathrm{H}_{12}: \mathrm{B}_{\mathrm{i}} \neq 0$ 
As shown in Table 2 the variable coefficient of the proportion of non- executive members to executive members is 0.319705 . According to t-statistic and $p$-value of this variable, we conclude that the coefficient is not significant at the 0.10 error- level. So $\mathrm{H}_{0}$ assumption of the second hypothesis is accepted.

\subsubsection{The third hypothesis}

The third hypothesis of the survey investigates whether there is a meaningful relationship between firm's auditing committee and intellectual capital of the pharmaceutical firms accepted in Tehran stock Exchange.

$\left.\mathrm{H}_{03}\right)$ There is not any meaningful relationship between firm's auditing committee and Intellectual capital of the pharmaceutical firms accepted in Tehran stock Exchange.

$\mathrm{H}_{03}: \mathrm{B}_{\mathrm{i}}=0$

$\left.\mathrm{H}_{13}\right)$ There is a meaningful relationship between firm's auditing committee and Intellectual capital of the pharmaceutical firms accepted in Tehran stock Exchange.

$\mathrm{H}_{13}: \mathrm{B}_{\mathrm{i}}$

As shown in Table 2 the variable coefficient of auditing committee (AUD) is equal to 0.531480 .

According to t-statistic and p-value of this variable, we conclude that the coefficient is not significant at the 0.10 error- level. So $\mathrm{H}_{0}$ assumption of the third hypothesis is accepted.

\subsubsection{The Impacts of control variables analysis}

Analyzing the impacts of control variables, existed in main model are as follows,

Return on assets (ROA) and natural logarithm of total assets have meaningful relationship with intellectual capital of the pharmaceutical firms accepted in Tehran stock Exchange when the level of significance is one percent. Therefore, we conclude that the greater a firm's ROA and total assets, the more is its intellectual capital.

\section{Conclusion}

According to this study corporate governance components have no special impact on pharmaceutical firm's intellectual capital. So firm's governors should reinforce their old and weak principles, wisely. By renewing these principles, they can be effective on intellectual caption as shown in related research. In recent decade, firms pay special attention to measuring intellectual capital to inform their beneficiaries. They want to find methods for evaluating internal intangible assets and extracting imperceptible values in organizations. In fact intellectual caption provides a new comprehensive model for observing the real value of organizations and calculating firm's future value and performance. The following suggestions could made based on the results of the survey,

1- The proposed model of this paper seems to be useful tool for firms to provide, to present and to analyze real and comprehensive financial statements in accounting system and to make good decisions for their future investments (buying other firm's equity)

2- This model is useful for investors and stock holders to have a real and correct measuring of now and future value of the firms (based on IC) for acquiring greater financial performance in future.

3- Because of extension in firms' activities and having need for specialized managers, it is recommended that firm's managing director be separated from board of directors in order to prevent any vagueness in these two institutions' duties and governing the firms. As well it is 
useful for reinforcing the responsiveness culture and enhancing information clarity in the firms and economical units. Because their assets are provided by a lot of stakeholders.

4- Because of the important role of non-executive members of the board in governing the firms, it is recommended that stakeholders and board members be more familiar to their supervisory role. Furthermore these non-executive members should be more knowledgeable about their duties towards forming different committees (i.e. auditing committee, appointment committee...) and their special reports in order to be more effective in governing the firms.

\section{References}

Ballas, A.A., Chalevas, C., \& Tzovas, C. (2012). Market reaction to valuation adjustments for financial instruments: Evidence from Greece. Journal of International Accounting, Auditing and Taxation, 21(1), 52-61 .

Chau, G., \& Leung, P. (2006). The impact of board composition and family ownership on audit committee formation: Evidence from Hong Kong. Journal of International Accounting, Auditing and Taxation, 15(1), 1-15 .

Chi, W., \& Wang, C. (2010). Accounting conservatism in a setting of Information Asymmetry between majority and minority shareholders. The International Journal of Accounting, 45(4), 465489.

Emamgholipour, M., Bagheri, S., Mansourinia, E \& Arabi, A. (2013). A study on relationship between institutional investors and earnings management: Evidence from the Tehran Stock Exchange. Management Science Letters, 3(4), 1105-1112.

Hentati, E \& Jilani, F. (2013). The determinants of non-audit fees in French firms. Management Science Letters, 3(6), 1773-1782.

Lu, W. M., Wang, W. K., Tung, W. T., \& Lin, F. (2010). Capability and efficiency of intellectual capital: The case of fabless companies in Taiwan. Expert Systems with Applications, 37(1), 546555.

Nassreddine, G \& Anis, J. (2012). Stakeholder approach, Stakeholders mental model: A visualization test with cognitive mapping technique. Management Science Letters, 2(2), 439-456.

Rouhi, F., \& Khalifehsultani, S. (2012). An investigate on relationship between moral hazard and corporate governance with earning forecast quality in the Tehran Stock Exchange. Management Science Letters, 2(8), 2795-2802.

Solomon, J., \& Solomon, A. (2004). Corporate Governance and Accountability. John Wiley and Sons, Ltd.

Valahzaghard, M \& Salehi, A. (2012). Impact of the corporate governance characteristics and ownership on earnings quality of the Islamic private banks in Iran. Management Science Letters, 2(7), 2607-2614. 